\title{
健診反復メニューに組み入れた注腸 $\mathrm{X}$ 線検查
}

\author{
具瀬実
}

我々は昭和 46 年開設以来メンバー制健診を続ける中 で，大腸癌早期発見の徹底を期すため，便潜血や自覚症 状の有無に関わらず直腸鏡検查を健診当日受診者全員に 行うと同時に，直腸鏡検查では結腸上部の䛦断は困難な ことを説明し, 受診者が注腸 X線検查を後日再来して受 けるよう極力説得するという方法をとって来た。

受診者には健診を受けている間に注腸 X線検查の必要 性を理解させる印刷物を読ませ，口頭でも説得する。

注腸X線検は苦しいという誤った先入観念はかなり多 くの受晾者が抱いて，ての文章による説明で検査の必要 性を理解して受ける気になり, 健診後の医師面接の際に 希望を申し出る者が 4 人に 1 人くらい有り, 総受診者数 の $11 \%$ が注腸 X線検查を受けた。

申し込み者の言葉には「てのあとすぐ受けたい」とい う内容が多く, 後日出直さねばならないと知ると, 申込 みを橴るか，予約までして州ってもキャンセルするとい うケースが多く, 注腸 $\mathrm{X}$ 線㭘査の受㡣率は当初全受診者 の $2 \sim 3 \%$ と低迷を続けた。

受喆者が注腸X線検査を受けたがらぬ理由は, 頻度の 高いものから，1. あう一度出直すのが面倒。2. 再来する 時間がない。3. 胃の検査も受けたのでX線の浴び過ぎが こわい。4. 聞いたことのない検査で心配。5. 腹具合も良 いし，そてまでする必要を感じない。6. そんな検査は恥 ずかしい。の順となる。嫌う理由の上位三つは，検査の 意義と必要性はすでに理解した者の言葉で,「わずらわ しさ」「いそがしさ」「被曝の恐怖」を解決してやれば済 むと考えられ, 健診当日に上部X線検査を健診メニュー 加抜き，代わりに注腸 X線検査を組み入れる方式を考 案し定期的に受診を反復するメンバーであって前回上部 X線検查に全く異常所見が無い者の場合に限る。

注腸 $\mathrm{X}$ 線検查を健診メニューに組み入れる基準は，下 記の通りとした。1. 健診で上部消化管 X線検査を済ませ
たメンバーにはまず 1 度注腸 X線㭘查を受けさせる。2. その後は平均的なりスクの者は 3 年に 1 回，ハイリスク （ 2 親等以内に腸癌有り）の者は 2 年に 1 回受けるよう 勧める。3.上部消化管 $\mathrm{X}$ 線検查に異常所見が有る者は健 診日外に, 精検の形で受けさせる。4. 注腸 X線を組み込 んだ健款を受ける者は正午近くスタートする最終の組に まとめる。

この方式で P L大阪健康管理センターを受站した 31,177 人のうち $11.3 \%$ に当たる 3,542 人が注腸 $\mathrm{X}$ 線検 査を受け, この中から結腸癌 30 例と直腸癌 29 例を発 見した。注腸 $\mathrm{X}$ 線検査の所要時間は平均 11.4 分之胃透 視なみに短縮されたが，上部消化管 $\mathrm{X}$ 線検查の済んだあ との透視台を使う関係上, 注腸 $\mathrm{X}$ 線検査を組み込んだ健 診を受りる者は正午近くスタートする最終の組にまとめ ることにしており，乙の時間帯はブラウン法前処置によ り腸壁の乾いた状態を作るのにあ好都合である。我々の 田近は注腸検査のルーティン化のため汇遠隔注腸装置を 考案した。これはバリウムと空気の注入スピードを操作 卓のコントローラー・スイッチで無段階に調節でき, 直 腸をあまり膨らさずにバリウムと空気が奥へ送り込むよ うタイミングを加減するととにより，受影者の苦痛を大 幅に軽減してやることができる。加圧・吸引は危険防止 の警報ブザーと自動停止回路とで，二重に安全を期して いる。検査終了の前に受診者を立位にし，バリウムを極 力直腸膨大部を導いておいて低圧で吸引し，カテーテル 抜去後の腹部膨満感を軽くするように努めている。

常習便秘の受診者の場合上行結腸に残便があり, 折角 の検査がしばしば非診断的なものに終る。予約の際必ず 問診し，便秘者には 3 日前加ら，強度の便秘には 7 日前 から生薬緩下凨アローゼンをのませるようにし，極めて 効果的であった。

\footnotetext{
Health Screening Examination Including Baviem Enema Study

PL 大阪健康管理センター
} 